\title{
UPAYA PENINGKATAN MINAT DAN PRESTASI BELAJAR MATEMATIKA SISWA DENGAN MENERAPKAN MODEL PEMBELAJARAN THINK PAIR SHARE (TPS) DI KELAS XII.MIPA.2 SMAN 3 MUARO JAMBI TAHUN PELAJARAN 2018/2019
}

\author{
HERMINA FLORIA BR GINTING \\ SMA Negeri 3 Muaro Jambi Provinsi Jambi \\ noor.anisah61@gmail.com
}

\begin{abstract}
ABSTRAK
Tujuan dari penelitian ini adalah untuk mengetahui peningkatan dari minat dan prestasi belajar Matematika siswa dengan menerapkan model pembelajaran Think Pair Share (TPS) di kelas XII.MIPA.2 SMA Negeri 3 Muaro Jambi Provinsi Jambi pada semester ganjil tahun pelajaran 2018/2019 pada pokok bahasan Matrik. Penelitian ini dilaksanakan di kelas XII.MIPA.2 di SMA Negeri 3 Muaro Jambi Provinsi Jambi pada semester ganjil tahun pelajaran 2018/2019 yang terdiri dari 36 siswa. Penelitian Tindakan Kelas (PTK) ini terdiri dari dua siklus. Tiap siklus terdiri dari empat tahap, yaitu perencanaan, tindakan, pengamatan dan refleksi. Hasil analisis minat belajar siswa pada siklus I dengan minat tinggi $25 \%$ dan minat rendah $41.67 \%$. Adapun prestasi belajar siswa yang sudah mencapai KKM pada siklus I mencapai $61.12 \%$. Pada siklus II hasil analisis mengalami peningkatan, yakni minat belajar tinggi naik menjadi 47.22 $\%$ dan minat belajar rendah turun sebesar $22.22 \%$. Prestasi belajar pada siklus II mengalami kenaikan, siswa yang sudah mencapai KKM menjadi sebesar $80.55 \%$. Hal ini menunjukkan hasil dari penelitian bahwa pembelajaran dengan menggunakan model pembelajaran Think Pair Share (TPS) dapat meningkatkan minat dan prestasi belajar siswa kelas XII.MIPA.2 semester ganjil di SMA Negeri 3 Muaro Jambi Provinsi Jambi pada tahun pelajaran 2018/2019.
\end{abstract}

Kata Kunci:minat dan prestasi belajar siswa, model pembelajaran think pair share.

\section{PENDAHULUAN}

Matematika sering kali menjadi pelajaran yang dianggap sulit untuk sebagian siswa. Hal ini terjadi karena pola pikir siswa belum sesuai dengan karakteristik matematika serta cara belajar yang kurang benar untuk materi matematika. Hal ini didukung oleh opini dalam masyarakat bahwa ketika ditanya pelajaran apa yang paling tidak disukai jawabannya adalah matematika. Akibat dari hal tersebut, prestasi belajar siswa untuk mata pelajaran matematika masih di bawah harapan. Untuk itu perlu adanya perubahan pola pikir pada siswa serta cara belajar siswa serta metode pembelajaran yang digunakan guru perlu ada perubahan. Seorang siswa perlu memiliki kemampuan memperoleh, memilih dan mengolah informasi untuk bertahan pada keadaan yang selalu berubah, tidak pasti dan kompetitif. Kemampuan tersebut membutuhkan kemampuan berpikir kritis, sistematis, logis, kreatif dan kemampuan bekerjasama yang efektif dan dapat dikembangkan melalui belajar matematika, karena matematika memiliki struktur dan keterkaitan yang kuat dan jelas antar konsepnya sehingga memungkinkan siswa terampil berpikir rasional, matematika mendasari perkembangan teknologi modern, mempunyai peran penting dalam berbagai disiplin dan memajukan daya pikir manusia, (Fuadi, dkk, 2016).

Prestasi belajar matematika siswa dipengaruhi oleh faktor dari dalam maupun dari luar siswa. Faktor yang mempengaruhi dari dalam diri siswa antara lain minat, intelegensi, kreativitas, dan gaya belajar siswa. Sedangkan faktor dari luar diri siswa mungkin metode/model yang digunakan guru dalam menyampaikan materi dan lingkungan siswa. Belajar pada hakikatnya adalah proses interaksi terhadap semua situasi yang ada di sekitar individu (Rusman, 2010:1). Belajar dapat dipandang sebagai proses yang diarahkan kepada tujuan dan proses berbuat melalui berbagai pengalaman. Slameto, (2010:2) berpendapat bahwa Belajar adalah suatu proses usaha yang dilakukan seseorang untuk memperoleh perubahan 


\section{SCIENCE : Jurnal Inovasi Pendidikan Matematika dan IPA Vol. 1 No. 2 Agustus 2021 e-ISSN : 2797-1031 | p-ISSN : 2797-0744}

tingkah laku yang baru secara keseluruhan sebagai hasil pengalamannya sendiri dalam interaksi dengan lingkungannya. Perubahan itu bersifat relative konstan dan berbekas.

Dari beberapa pandangan di atas dapat disimpulkan bahwa seseorang dikatakan belajar apabila terjadi perubahan pada dirinya akibat adanya latihan dan pengalaman melalui interaksi dengan lingkungan. Belajar adalah proses pengembangan dan kami dapat mengartikan ini sebagai sebuah proses pengembangan yang mengakibatkan atau menghasilkan perubahan tanggapan. Dengan begitu yang dimaksud belajar adalah adanya perubahan dalam tanggapan pada seseorang yang menuju ke arah perkembangan.

Selama ini masih banyak Guru masih menggunakan metode/model konvensional. Guru hanya mentransfer pengetahuan kepada siswa secara satu arah, siswa belajar hanya dengan mendengarkan dan mencatat pelajaran, siswa tidak memahami konsep karena siswa hanya menghafal rumus sehingga tidak ada kebermaknaan dalam mempelajari materi tersebut yang sebenarnya banyak aplikasinya dalam kehidupan sehari-hari. Kelas XII.MIPA.2 adalah kelas yang terdiri atas 36 siswa. Dalam hasil ulangan pada materi program linier sebelumnya rata rata untuk prstasi belajar matematika masih berada paling bawah diantara 3 kelas yang lain.

Menurut Djamarah (2012: 19) prestasi adalah hasil dari suatu kegiatan yang telah dikerjakan, diciptakan baik secara indiviual maupun kelompok. Sedangkan belajar adalah suatu aktivitas yang dilakukan secara sadar untuk mendapatkan sejumlah kesan dari bahan yang telah dipelajari. Dari pengertian tersebut erat kaitannya antara prestasi dengan belajar, ketika seseorang bersungguh-sungguh dalam belajar maka akan mendapat prestasi yang diharapkan. Sehingga menurut Djamarah (2012: 23) prestasi belajar adalah hasil yang diperoleh berupa kesan-kesan yang mengakibatkan perubahan dalam diri individu sebagai hasil dalam aktivitas dalam belajar. Sedangkan Menurut Fathurrohman dan Sulistyorini (2012: 119) "prestasi belajar adalah hasil dari suatu kegiatan yang berupa perubahan tingkah laku yang dialami subyek belajar di dalam suatu interaksi dengan lingkungannya. "Prestasi beajar tidak akan pernah dihasilkan selama seseorang tidak melakukan suatu kegiatan secara bersungguh-sungguh dalam belajar. Dalam kenyataannya, untuk mendapatkan prestasi belajar yang baik tidak semudah yang dibayangkan, tetapi penuh perjuangan dengan berbagai tantangan yang harus dihadapi untuk mencapainya. Prestasi belajar merupakan tolak ukur yang dapat digunakan untuk menentukan tingkat keberhasilan siswa dalam mengetahui dan memahami suatu mata pelajaran, biasanya dinyatakan dengan nilai yang berupa huruf atau angka-angka.

Prestasi belajar matematika sangat dipengaruhi oleh proses pembelajaran matematika di kelas. Pembelajaran yang dilakukan oleh guru pada umumnya masih didominasi oleh pembelajaran langsung di mana suasana kelas cenderung teacher-centered (berpusat pada guru) sehingga siswa menjadi pasif. Rendahnya prestasi belajar siswa di Kelas XII.MIPA.2 SMA Negeri 3 Muaro Jambi berkaitan erat dengan minat belajar siswa terhadap mata pelajaran Matematika. Selama ini, persepsi yang berkembang diantara siswa yakni mata pelajaran Matematika merupakan pelajaran yang sangat sulit untuk dipelajari. Persepsi negatif tersebut semakin diperburuk dengan minat siswa yang tergolong rendah. Dari 36 siswa sekitar 78\% diantaranya masih mengganggap Matematika adalah pelajaran yang sangat sulit, walaupun secara umum mereka berminat untuk mengambil jurusan MIPA. Padahal dalam belajar matematika agar siswa dapat memahami matematika secara konseptual seharusnya siswa perlu saling berinteraksi dengan teman maupun guru. Menelaah, menghubungkan keterkaitan konsep, membuat dugaan cara penyelesaian dan jawaban atas masalah yang dipelajari, serta mendiskusikan gagasan mereka sendiri. Oleh sebab itu guru perlu memperhatikan pemilihan model pembelajaran yang menyenangkan dan membuat siswa aktif. Minat sangat besar pengaruhnya terhadap aktivitas belajar. Menurut Crow and Crow dalam Djaali (2011: 121) "minat berhubungan dengan gaya gerak yang mendorong seseorang untuk menghadapi atau berurusan dengan orang, benda, kegiatan, pengalaman, yang di rangsang oleh kegiatan itu sendiri", sehingga dapat diambil pengertian bahwa individu yang mempunyai minat terhadap belajar, maka akan terdorong untuk memberikan perhatian terhadap belajar tersebut (Gupita, 2016). 


\section{SCIENCE : Jurnal Inovasi Pendidikan Matematika dan IPA Vol. 1 No. 2 Agustus 2021 e-ISSN : 2797-1031 | p-ISSN : 2797-0744}

Fakta menunjukkan bahwa banyak guru di Indonesia mengalami banyak kesulitan dalam mengajarkan matematika kepada siswa. Hal ini terjadi karena pembelajaran yang dilakukan guru sangat membosankan. Berdasarkan hal tersebut, minat siswa terhadap matematika menjadi berkurang. Di dalam dunia pendidikan, kejadian seperti ini merupakan masalah besar yang harus segera diselesaikan (Ribut, 2017). Salah satu mata pelajaran di sekolah yang sering kurang diminati siswa adalah mata pelajaran matematika. Dengan belajar matematika siswa merasa bingun dan tertekan ketika belajar. Salah satu upaya yang dilakukan untuk menyelesaikan permasalahan tersebut adalah dengan pembelajaran kooperatif. Salah satu tipe dalam pembelajaran kooperatif adalah tipe think pair share (TPS) yang dapat mengembangkan belajar aktif serta memungkinkan pembelajaran siswa untuk lebih banyak berfikir, merespons, berdiskusi, dan saling tukar pikiran sama lain (Faqih, 2017). Pembelajaran Koperatif Think Pair Share adalah suatu mode pembelajaran yang memberi siswa waktu untuk berpikir dan merespon serta saling bantu satu sama lain. Model ini memperkenalkan ide "waktu berpikir atau waktu tunggu" yang menjadi faktor kuat dalam meningkatkan kemampuan siswa dalam merespon pertanyaan. Pembelajaran kooperatif model think pair shareini relatif lebih sederhana karena tidak menyita waktu yang lama untuk mengatur tempat duduk ataupun mengelompokkan siswa. Pembelajaran ini melatih siswa untuk berani berpendapat dan menghargai pendapat teman (Shoimin, 2015: 208).

Dalam menghadapi persoalan diatas guru dituntut untuk bisa mengatasi masalah. Guru harus memiliki kreativitas untuk memilih strategi atau model pembelajaran yang sesuai yaitu model pembelajaran yang melibatkan siswa aktif dalam proses pembelajaran. Salah satu cara guru untuk memilih model pembelajaran yang disukai siswa yaitu guru harus memahami karakteristik siswa, bahwa sebagian besar siswa menyukai diskusi dengan teman sebangkunya padahal diskusi yang dibahas antar teman sebangku tidak menyangkut mata pelajaran Matematika (Hasri, 2021). Untuk itu guru dapat mengubah model pembelajaran yang terkait dengan hal yang disukai siswa yaitu model pembelajaran yang dilaksanakan secara diskusi berpasangan. Model pembelajaran yang langkah-langkahnya dilaksanakan secara berpasangan adalah model pembelajaran kooperatif tipe Think Pair Share (TPS), karena diskusi secara berpasangan akan lebih mudah dalam menyatukan pendapat, mengoptimalkan partisipasi siswa dan menumbuhkan sikap sosial siswa untuk bekerja sama (Kurniasih, 2018).Model pembelajaran kooperatif merupakan suatu aktivitas pembelajaran yang dapat memberikan siswa kesempatan untuk saling berbagi pemikiran serta solusi dalam memecahkan suatu masalah. Dengan menerapkan model pembelajaran kooperatif tipe Think Pair Share diharapkan dapat meningkatkan partisipasi siswa serta memberikan lebih banyak kesempatan kontribusi pada masing-masing anggota kelompok, hal ini dikarenakan model pembelajaran kooperatif tipe Think Pair Share ini hanya beranggotakan dua orang siswa (Wulandari, 2017).

Studi Tsay dan Brady (2010) menemukan bahwa ada hubungan positif antara pembelajaran kooperatif dankinerja akademik, dan dalam pendidikan siswa sekaligus kemampuan siswa dalam berkomunikasi. Jika siswa sering berkomunikasi dengan baik dengan guru dan teman-teman maka pemahaman mereka tentang materi akan meningkat. Temuan ini mendukung fakta bahwa pembelajaran kooperatif dapat menjadi metode pengajaran dan pembelajaran yang baik untuk mencapai kinerja akademik yang tinggi. Penelitian yang berkaitan dengan pembelajaran kooperatif telah dilakukan di berbagai negara, tidak terkecuali di Indonesia. Misalnya, Mustaqim, dkk (2012) telah melakukan studi tentang efek pembelajaran kooperatif siswa SMP Indonesia menggunakan metode Think Pair Share. Hasil penelitian menunjukkan bahwa metode pembelajaran kooperatif Think Pair Share lebih efektif daripada metode konvensional.

Prestasi belajar siswa yang dicapai dimungkinkan tidak hanya dipengaruhi oleh model pembelajaran yang diterapkan di dalam kelas. Terdapat faktor-faktor lain yang mempengaruhi prestasi belajar matematika yang juga perlu mendapat perhatian dari guru,misalnya minat belajar yang dimiliki oleh siswa. minat diartikan sebagai kecenderungan yang menetap, untuk merasa tertarik pada bidang studi atau pokok bahasan tertentu dan merasa senang mempelajari 
materi itu. Siswa yang berperasaan senang akan mudah berkonsentrasi dalam belajar (Jatmiko, 2015).

\section{METODE PENELITIAN}

Penelitian ini merupakan Penelitian Tindakan Kelas (Classroom Action Re-search) yang biasa disingkat dengan PTK. Penelitian ini dilakukan di Kelas XII.MIPA.2 semester ganjil SMA Negeri 3 Muaro Jambi Provinsi Jambi pada tahun pelajaran 2018/2019.

Subjek penelitian yang dikenai tindakan adalah siswa Kelas XII.MIPA. 2 semester ganjil SMA Negeri 3 Muaro Jambi Provinsi Jambi pada tahun pelajaran 2018/2019. Siswa tersebut belum pernah mendapatkan model pembelajaran kooperatif tipe Think Pair Share(TPS).

Pengumpulan data pada penelitian ini menggunakan Observasi dan Catatan Lapangan (angket). Catatan lapangan digunakan untuk mengumpulkan data di lapangan mengenai aktivitas yang terjadi selama proses belajar mengajar. Pelaksanaan Tes dilakukan pada akhir siklus untuk mengetahui pemahaman akhir siswa yang digunakan sebagai acuan perencanaan pembelajaran pada siklus berikutya. Teknik Analisis Data dalam penelitian ini meliputi reduksi data, deskripsi data dan mendeskripsikan data yang telah diorganisir jadi bermakna. Mendeskripsikan data bisa dilakukan dalam bentuk tabel atau grafik.

Indikator Kerja Dalam penelitian ini, dapat diketahui dari adanya peningkatan minat dan prestasi siswa dalam mengikuti kegiatan pembelajaran. Dengan adanya peningkatan minat dan prestasi belajar siswa dalam mengikuti pembelajaran diharapkan adanya peningkatan nilai rata-rata prestasi belajar siswa. Nilai yang diambil selama kegiatan pembelajaran dalam penelitian ini meliputi: 1) Siswa dikatakan mempunyai prestasi belajar matematika yang meningkat jika hasil formatif di akhir siklus minimal $80 \%$ dari seluruh siswa mendapat nilai minimal 77 dengan Kriteria Ketuntasan Minimal (KKM) materi pokok bahasan matriks. 2) Siswa dikatakan berhasil dalam meningkatkan minat belajarnya jika hasil pengamatan di akhir siklus minimal $80 \%$ dari seluruh siswa mendapat kategori baik. Jika $\geq 80 \%$ dari seluruh siswa mendapat kategori baik, maka pembelajaran dengan menggunakan model pembelajaran kooperatif tipe Think Pair Share(TPS) berhasil dalam meningkatkan minat belajar siswa.

Penelitian tindakan kelas ini dilakukan dalam teknik siklus. Tiap siklus dilaksanakan sesuai dengan perubahan yang dicapai. Untuk penentuan kelas penelitian digunakan acuan adalah nilai rata-rata ulangan harian dan ulangan akhir semester adapun rincian siklus sebagai berikut: Siklus I meliputi (1) perencanaan pengembangan (plan) I, (2) pelaksanaan tindakan (action) I, (3) pengamatan (ob- servation) I, (4) refleksi tindakan (reflection) I. Siklus II meliputi (1) perencanaan pengembangan (plan) 2 , (2) pelaksanaan tindakan (action) 2, (3) pengamatan (observation) 2, (4) refleksi tindakan (reflection) 2.

\section{HASIL DAN PEMBAHASAN}

\section{Siklus I}

Perencanaan, Peneliti menyusun perangkat pembelajaran seperti silabus, RPP, lembar aktivitas siswa, latihan kemampuan, tes formatif, tes unit, lembar pengamatan, angket siswa untuk mendukung pembelajaran kooperatif tipe Think Pair Share (TPS).

Pelaksanaan, Dalam pelaksanaan tindakan kelas ini yang bertindak sebagai guru adalah peneliti dan dibantu oleh kolaborator sebagai pengamat aktivitas siswa dan guru.

Hasil pengamatan, berdasarkan nilai pada tes prestasibelajar matematika pada siklus I didapat hasil sebagai berikut:

Tabel 1. Rata-rata nilai per kelompok Siklus I

\begin{tabular}{ccccccccc}
\hline Kelompok & 1 & 2 & 3 & 4 & 5 & 6 & 7 & 8 \\
\hline \multirow{2}{*}{ Rerata } & 75, & 68, & 77, & 75, & 67, & 65, & 63, & 63, \\
& 80 & 60 & 40 & 40 & 50 & 00 & 25 & 25 \\
\hline
\end{tabular}


Dari tabel di atas, diperoleh rata-rata nilai pada siklus $\mathrm{I}=74,86$. Nilai tertinggi yang mampu dicapai pada siklus I adalah 91 sedangkan nilai terendah yang dicapai pada siklus I adalah 50. Untuk lebih jelasnya tersaji dalam hasil penilaian siklus I.

Minat belajar siswa diukur menggunakan angket yangdiisi oleh siswa dan terdiri atas 40 pertanyaan dengan 4 pilihan jawaban seperti pada

lampiran. Masing-masing komponen ini diberikan skala nilai 1-4. Adapun hasil pengamatan minat belajar siswa pada siklus I adalah sebagai berikut:

Tabel 2. Rata-rata Minat Belajar Siklus I

\begin{tabular}{cccc}
\hline Kelompok & Minat tinggi & Minat sedang & Minat rendah \\
\hline Banyaknya & 9 & 12 & 15 \\
$($ dalam \%) & 25 & 33,33 & 41,67 \\
\hline
\end{tabular}

Dari tabel di atas, diperoleh minat rendah paling banyak yaitu 41,67 \%. Untuk lebih jelasnya tersaji dalam minat belajar siklus I. Adapun siswa yang mampu mencapai KKM berdasarkan hasil penilaian siklus I, siswa yang mampu mencapai KKM sebanyak 22 siswa dari 36 siswa, dengan rincian sebagai berikut:

Tabel 3. Pencapaian KKM Siklus I

\begin{tabular}{c|cc}
\hline SiklusI & $\begin{array}{c}\text { Sudah Mencapai } \\
\text { KKM }(\%)\end{array}$ & Belum Mencapai \\
Banyaknya & 22 & 14 \\
Dalam(\%) & 61,12 & 38,88 \\
\hline
\end{tabular}

Refleksi, Dari hasil pengamatan peneliti, terlihat bahwa rata-rata nilai siswa masih dibawah dari KKM. Meskipun sudah ada 22 siswa yang nilainya diatas KKM namun masih 38,88 \% siswa yang belum mampu mencapai KKM yang ditetapkan. Untuk itu penelitian dilanjutkan pada siklus II.

Tabel 4. Rekpitulasi Hasil Siklus I

\begin{tabular}{cccc}
\hline Keterangan Siklus & $\begin{array}{c}\text { Rata rata } \\
\text { Prestasi } \\
\text { belajar }(\%)\end{array}$ & $\begin{array}{c}\text { Yang } \\
\text { tuntas }(\%)\end{array}$ & $\begin{array}{c}\text { Yang tidak } \\
\text { tuntas }(\%)\end{array}$ \\
\hline Siklus I & 74,86 & 61,12 & 38,88 \\
\hline
\end{tabular}

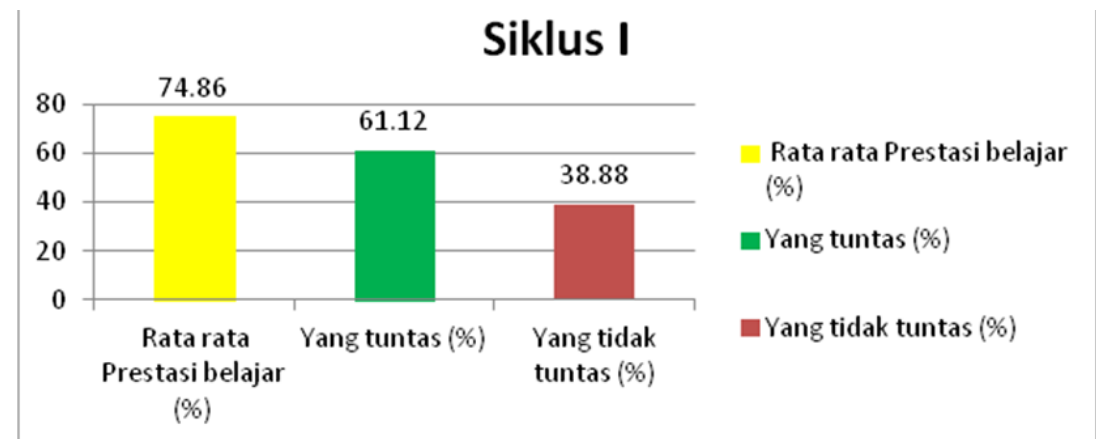

Gambar 1. Grafik Ketuntasan Belajar Siswa Siklus I

Dari hasil pada siklus I dapat disimpulkan bahwa masih terdapat siswa yang mempunyai minat sedang dan rendah dikarenakan pada siklus I siswa masih belum terbiasa dengan model pembelajaran yang dilaksanakan sehingga berakibat pada nilai prestasi belajar masih banyak 
yang di bawah KKM. Disamping itu peneliti dalam melakukan pembelajaran masih kurang merata dalam mengobservasi siswa yang mengalami kesulitan dan membantunya serta peneliti belum terbiasa dalam model pembelajaran sehingga ada beberapa tahap yang kurang maksimal. Namum hasil refleksi siswa mayoritas mereka meara senang dengan model yang digunakan. Sehingga kekeurangan ini akan di perbaiki dalam siklus II.

\section{Siklus II}

Berdasarkan nilai hasil tes prestasi belajar pada siklus II diperoleh rata-rata nilai tiaptiap kelompok sebagai berikut:

Tabel 6. Rata-rata Nilai perkelompok Siklus II

\begin{tabular}{rcccccccc}
\hline Kelompok & 1 & 2 & 3 & 4 & 5 & 6 & 7 & 8 \\
\hline Rata-rata & 83,0 & 76,6 & 81,4 & 81,2 & 86,5 & 83,5 & 83,5 & 74,2 \\
& 0 & 0 & 0 & 0 & 0 & 0 & 0 & 5 \\
\hline
\end{tabular}

Dari tabel di atas, diperoleh rata- rata nilai pada siklus II $=81,31$. Nilai tertinggi yang mampu dicapai pada siklus II adalah 95 sedangkan nilai terendah yang dicapai pada siklus II adalah 65. Untuk lebih jelasnya tersaji dalam lampiran 12 hasil penilaiann siklus II.

Adapun minat belajar siswa, Seperti pada siklus I, minat belajar siswa diukur menggunakan 40 komponen, masing-masing komponen memiliki skala penilaian 1-4. Pada siklus II ini, keaktivan siswa sudahmulai tampak, hal tersebut terlihat dari ada siswa yang bersedia mengerjakan soal latihan kemampuan di papan tulis. Pada saat ada beberapa siswa yang kesulitan mengerjakan soal, kemudian satu diantara siswa maju untuk mengerjakan soal yang ditanyakan tersebut. Hal tersebut menunjukkan bahwa minat belajar sudah mulai ada peningkatan. Adapun hasil pengamatan mengenai prosentase minat belajar siswa pada siklus II secara keseluruhan adalah sebagai berikut:

Tabel 7. Rata-rata Minat Belajar Siklus II

\begin{tabular}{cccc}
\hline Kelompok & $\begin{array}{c}\text { Minat } \\
\text { tinggi }\end{array}$ & $\begin{array}{c}\text { Minat } \\
\text { sedang }\end{array}$ & $\begin{array}{c}\text { Minat } \\
\text { rendah }\end{array}$ \\
\hline Banyaknya & 17 & 11 & 8 \\
\hline Dalam(\%) & 47,22 & 30,56 & 22,22 \\
\hline
\end{tabular}

Siswa yang mampu mencapai KKM berdasarkan hasil penilaiann siklus II, siswa yang mencapai KKM sebanyak 22 siswa dari 35 siswa, sehingga prosentasenya adalah:

Tabel 8. Pencapaian KKM Siklus II

\begin{tabular}{ccc}
\hline & Sudah Mencapai & Belum Mencapai \\
Siklus II & $\operatorname{KKM}(\%)$ & $\operatorname{KKM}(\%)$ \\
Banyaknya & 29 & 7 \\
Dalam $(\%)$ & 80,55 & 19,45 \\
\hline
\end{tabular}

Berdasarkan hasil pengamatan pada siklus II, terjadi peningkatan yang cukup baik. Rata-rata nilai siswa kelas XII.MIPA.2 dari 74,86 meningkat menjadi 81,31. Minat belajar dari minat rendah 15 siswa menjadi 8 siswa, minat sedang 12 menjadi 11 siswa sedangkan minat tinggi dari 9 siswa menjadi 17 siswa. Prosentase siswa yang mencapai KKM meningkat dari 22 menjadi 29 sedangkan yang belum men- capai KKM turun dari 14 menjadi 7 siswa. 
SCIENCE : Jurnal Inovasi Pendidikan Matematika dan IPA Vol. 1 No. 2 Agustus 2021 e-ISSN : 2797-1031 | p-ISSN : 2797-0744

Tabel 9. Hasil Siklus II

\begin{tabular}{cccc}
$\begin{array}{c}\text { Keterangan } \\
\text { Siklus }\end{array}$ & $\begin{array}{c}\text { Rata rata } \\
\text { Prestasi } \\
\text { belajar }(\%)\end{array}$ & $\begin{array}{c}\text { Yang } \\
\text { tuntas(\%) }\end{array}$ & $\begin{array}{c}\text { Yang tidak } \\
\text { tuntas(\% } \\
)\end{array}$ \\
\hline Siklus II & 81,3 & 80,55 & $\begin{array}{c}19,4 \\
5\end{array}$ \\
\hline
\end{tabular}

Jika ditampilkan dalam grafik adalah sebagai berikut :

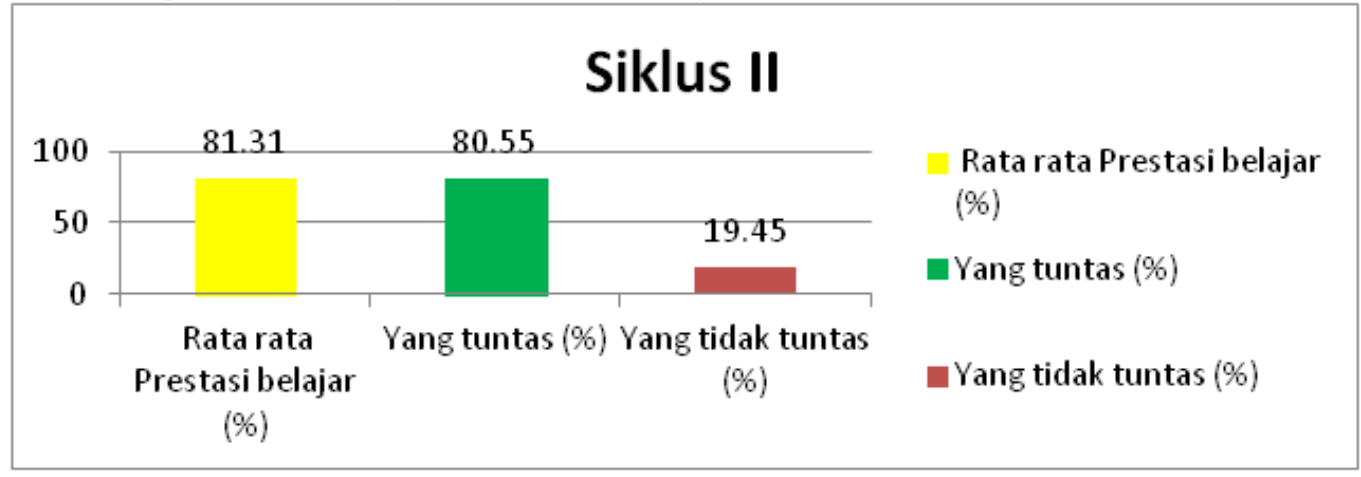

Gambar 2. Grafik Ketuntasan Belajar Siklus II

\section{KESIMPULAN}

Penelitian tindakan kelas menggunakan model pembelajaran kooperatif tipe Think Pair Share (TPS)pada pokok bahasan matriks, kelas XII.MIPA.2 di SMA Negeri 3 Muaro Jambi tahun pelajaran 2018/2019 yang dilaksanakan selama 2 siklus diperoleh hasil sebagai berikut: 1) Bahwa penerapan model pembelajaran kooperatf tipe Think Pair Share (TPS) dapat meningkatkan minat belajar siswa kelas XII.MIPA.2 SMA Negeri 3 Muaro Jambi tahun pelajaran 2018/2019 pada pokok bahasan matriks. 2) Bahwa penerapan model pembelajaran kooperatif tipe Think Pair Share (TPS) dapat meningkatkan prestasi belajar siswa kelas XII.MIPA.2 SMA Negeri 3 Muaro Jambi tahun pelajaran 2018/2019 pada pokok bahasan matriks. 3) Berdasarkan hasil penelitian ini dapat dijadikan pertimbangan untuk memilih metode atau pendekatan mengajar yang tepat, agar pengajar dalam memberikan materi sesuai dengan tujuan yang diharapkan.

\section{DAFTAR PUSTAKA}

Djaali. (2011). Psikologi Pendidikan. Jakarta: Bumi Aksara

Djamarah, Syaiful B. (2012).Prestasi Belajar dan Kompetensi Guru.Surabaya: PT Usaha Nasional.

Faqih, A. (2017). Model Think Pair Share: Apakah Mempengaruhi Pemahaman Konsep Matematika? JNPM (Jurnal Nasional Pendidikan Matematika), 3(1), 40-50.

Fuadi, R., Johar, R., \& Munzir, S. (2016). Peningkatkan kemampuan pemahaman dan penalaran matematis melalui pendekatan kontekstual. Jurnal Didaktik Matematika, 3(1), 47-54.

Gupita, N. (2016). Peningkatan Minat, Keaktifan dan Prestasi Belajar Matematika Dengan Model Pembelajaran kooperatif Tipe Think Pair Share Pada Siswa Kelas VII A SMP PGRI Bagelen Tahun Pelajaran 2015/2016 (Doctoral dissertation, Pendidikan Matematika-FKIP).

Hasri, H. (2017). Peningkatan Minat Belajar Siswa Melalui Penerapan Model Kooperatif Tipe Think Pair Share (TPS) pada Mata Pelajaran Matematika. Didaktika: Jurnal Kependidikan, 10(2), 79-86.

Jatmiko, J. (2015). Eksperimen model pembelajaran think-pair-share dengan modul (TPS-M) terhadap prestasi belajar matematika ditinjau dari minat belajar. JIPM (Jurnal Ilmiah Pendidikan Matematika), 3(2). 
Kurniasih, D. (2017). Peningkatan minat dan hasil belajar MIPA melalui model pembelajaran think pair share. Natural: Jurnal Ilmiah Pendidikan MIPA, 5(1), 7-11.

Mustaqim, B. (2012). Eksperimentasi Model Pembelajaran Kooperatif Tipe Think Pair Share (Tps) Dan Mood Understand Recall Detect Elaborate Review (Murder) Pada Materi Pokok Logaritma Ditinjau Dari Minat Belajar Siswa Kelas X Smk Se Kabupaten Karanganyar.

Ribut, O. (2017). Pengaruh Model Pembelajaran Kooperatif Think Pair Share (TPS) Pada Prestasi matematika Siswa Sekolah Menengah Pertama. Jurnal Jendela Pendidikan, 1(1), 1-6.

Shoimin, A. (2016). Model Pembelajaran Inovatif dalam Kurikulum 2013. Yogyakarta: ArRuzz Media

Tsay, M., \& Brady, M. (2010). A Case Study of Cooperative Learning and Communication Pedagogy: Does Working in Teams Make a Difference? Journal of the Scholarship of Teaching and Learning, 10(2), 78-89.

Wulandari, T. (2017). Penggunaan Model Pembelajaran Kooperatif Tipe Think Pair Share untuk Meningkatkan Prestasi Belajar Matematika pada Materi Program Linear. Absis: Mathematics Education Journal, 2(1), 18-23. 